\title{
The Transformation of Educational Management in the Disruption Era
}

\author{
Herman \\ Sekolah Tinggi Agama Islam Negeri Teungku Dirundeng Meulaboh \\ E-mail: herman@staindirundeng.ac.id
}

\begin{abstract}
Abstrak
Artikel ini menjelaskan tentang transformasi manajemen pendidikan di era disrupsi. Ini dapat mendorong staf sekolah dan pemangku kepentingan lainnya untuk melakukan perbaikan, perubahan, dan inovasi dari sistem tradisional atau manual ke sistem digitalisasi seperti aplikasi MOOC (Massive Open Online Course) dan AI (Artificial Intelligence) yang dapat menciptakan kemudahan, keringanan, dan percepatan dalam meningkatkan kualitas program pendidikan. Penelitian ini menggunakan metode kualitatif dengan pendekatan deskriptif melalui studi pustaka. Teknik penulisan dilakukan melalui beberapa tahapan mulai dari tahap pengumpulan data hingga tahap pengolahan dan analisis data yang dianggap relevan dan memiliki hubungan dengan permasalahan penelitian. Berdasarkan hasil penelitian menunjukkan bahwa transformasi manajemen pendidikan di era disrupsi meliputi: 1) transformasi manajemen pendidikan yang berpusat pada pencapaian mutu pelayanan dan lulusan, 2) kepemimpinan yang memiliki visi dan misi yang membuat kebijakan yang konkrit dan transparan, 3) pengorganisasian sumber daya manusia yang mampu melakukan perbaikan, perubahan dan inovasi, dan 4) membangun budaya kerja yang menghasilkan dan menghasilkan indikator kinerja.
\end{abstract}

Kata Kunci: Transformasi, Manajemen Pendidikan, Era Disrupsi

\begin{abstract}
This article describes the transformation of educational management in the disruption era. It could encourage school's staff and other stakeholders to make improvements, changes, and innovations from traditional or manual systems to digitalization systems such as the MOOC (Massive Open Online Course) application and AI (Artificial Intelligence) which could create convenience, relief, and acceleration of improving the quality of educational program. This study used qualitative method with descriptive approach through library research. The writing technique was carried out through several stages started from the
\end{abstract}


data collection stage to data processing and analysis stage that was considered relevant and had relationship with the problems of the study. Based on the result, it shows that the transformation of educational management in the disruption era includes: 1) transforming educational management that is centered on the achievement of service quality and graduates, 2) leadership which has vision and mission that create concrete and transparent policies, 3) organizing the human resources who are capable of making improvements, changes and innovations, and 4) building a work culture that produces and generates the indicators of performance.

Keywords: Transformation, Educational Management, Disruption Era

\section{INTRODUCTION}

In the disruption era, all aspects of life have fundamentally changed. Making fundamental change is a part of disruption era in transforming the educational management (Farid Abdullah, 2019). It is an opportunity to answer some challenges of the industrial revolution 4.0 (Hairiah, 2015; Khoiri, 2020). It also could encourage improvements, changes, and innovations to educational problems that are considered less relevant to the current era (Fitri, 2020). The transformation of management could be carried out through the disruption of digitalization system which gives various concepts of application including MOOC (Massive Open Online Course) and AI (Artificial Intelligence). These applications facilitate, ease, and accelerate the process of improving the quality of the implementation of educational program (Mayling, et., Al., 2017).

The transformation of management in educational institution should not be stagnant which could give weak enthusiasm for improvement and changes in the implementation of a better educational program and also to move forward (Zulela, 2020: 2). It should also focus on the improvement and changes in the form, model and system for achieving the good quality of service, graduates, vision and mission that create concrete and transparent policies, improvements to the work system and create clear and measurable indicators of performance (Bohemia, et.al., 2014).

The management of educational institution must be centered on the quality of academic services and graduates, so that all parties who take educational program will get optimal satisfaction. Therefore, the leaders of education institution must have serious attention to the regulation and management which is centered on the quality of academic services and graduates 
(Herman, 2020). The quality of services could provide satisfaction to the members of education, parents of students, and community likewise, the qualified graduates will be easily meet the need when they find a job and they could be accepted by all elements of the organization and society. The quality of academic services and graduates must have clear standards and criteria in the implementation of educational programs.

The vision and mission of educational institution could be transformed to produce concrete and transparent policies as basic principles in managing educational institution (Hayat: 2014). The vision and mission formulated must produce concrete policies on programs and activities to be carried out by the educational stakeholders. If the vision and mission fail to produce concrete policies, the implementation of educational programs will disappear and be void in achieving educational goals. These concrete policies must be transparent to the members of educational institution, so that the programs and activities are easy to control and supervise.

The leadership style also affects the level of quality of work culture (Ali, et.al., 2015). Work culture could be transformed to produce the indicators of performance that could be assessed and measured according to the standards formulated by the educational institution (Rouf, 2016; Jamaluddin, et.al., 2017). A good work culture is a work culture that is connected to the elements of humans (man), funds (money), methods (methods), and facilities (machines). These elements support one another in managing the educational institutions.

These days, there are also some educational stakeholders who are not brave enough to make improvements and changes in the management of educational institution, so there is stagnation of the transformation of educational management in the disruption era. This is due to the weak competence and leadership skills of educational institution in transforming educational management and they are trapped with the traditional system. "The leadership of educational institution should have a fundamental obligation to carry out a transformation that could produce qualified output through improving the quality of service processes that could increase the result of qualified output (Hairiyah: 2015).

Based on the description of the problems above, the researchers are very interested in discussing the transformation of educational management in the disruption era. The focus of the discussion is on the transformation of 
educational management that is centered on the quality of service and graduates, vision and mission that create concrete and transparent policies, organizing human resources that is centered on improvements, changes and innovations as well as a work culture that creates the indicators of performance.

The study of the transformation of educational management in the disruption era would give the good benefits to the educational leaders and other stakeholders. Its transformation could encourage the leaders and stakeholders to disrupt the management of unit, reform the educational program, improve the quality of academic service and graduates. The disruption of the transformation of educational management will lead to increase the superior, productive, and competitive human resources because the parties who do the disruption are the leaders and other members of the educational unit.

\section{RESEARCH METHOD}

This research used library research method to analyze the transformation of educational management in the disruption era. This library research was conducted to identify the leadership problems, educational management, quality of academic service, organization of human resource, and culture of work. Processing data was seen from various literatures as secondary data. (Kartini Kartono, 1996). The approach of the research was descriptive qualitative. The technique of analyzing data was by describing the concept dan theories about the transformation of educational process focusing on the quality of service, leadership that has clear vision, organization of human resource, and culture of work. The whole data was analyzed to describe the concept of the transformation of educational management in the disruption era (Nazir Mohammad, 1988).

\section{RESULTS AND DISCUSSION}

\section{The Transformation Concept of Educational Management in the Disruption} Era

Transformation comes from the word to transform which means to change something into a different form. For example; transforming vision into reality, heat into energy, latent into manifest which becomes a change in form or action from the previous condition (Maisarah: 2019).

Educational management is basically a process of managing and empowering all resources effectively and efficiently through planning, 
organizing, leadership and controlling practices (Mahmud, 2019). In other words, educational management is a series of efforts to regulate and manage an educational institution, so that all management functions could run effectively and efficiently to achieve the goals.

The main objective of educational management is to assist educational institution in maximizing all resources to achieve the goals (Mahmud, 2019). The management of education is more directed at increasing the quality of services in the provision of comprehensive educational programs including the quality of graduates.

In order to achieve the goal, the whole educational stakeholders who are actively involved in carrying out the functions of educational management should implement the integrated programs and activities. (Mahmud, 2019). These functions start from the planning process to the implementation, monitoring, evaluation of the programs and the activities of the programs. The more active and creative the members of educational unit in implementing the functions of management, the more qualified they will be in managing the educational unit.

The transformation of educational management has become a demand in the disruption era because with the advances of technology, information, and communication will encourage the leaders of educational to transform the management by disrupting the policy, technical guidance of the implementation of educational program. The disruption is carried out to enhance the use of technology such as MOOC (Massive Open Online Course) and AI (Artificial Intelligence) which can facilitate and accelerate the process of improving the quality of educational programs. (Hairiyah, 2015).

The management of education must always be disrupted, leading to improvements and changes in forms, models and systems of academic and student services. The quality of educational services is disrupted with the aim of increasing the satisfaction of members of the education unit, parents of students, and the community. The quality of graduates is disrupted by creating the superior, competitive, and innovative students so that they can adapt to the job market. The quality of academic and student services must have standardized and credible criteria in academic and student services in schools.

The leader of the education unit has the obligations to carry out disruption related to the service process that can provide the optimal quality of 
output and to build a good culture of work. The culture of work is obliged to be disrupted by the leader to connect all elements like humans, funds, methods, and facilities in implementing the educational programs. (Abdul Rouf, 2016). All of these elements must be the main concern for a leader in managing an educational unit because the key to a successful management of an educational unit is very much dependent on how the leadership could manage these elements.

\section{Conceptual Framework for Designing the Transformation of Educational Management in the Disruption Era}

The design of the conceptual framework for the transformation of educational management in the disruption era is as follows:

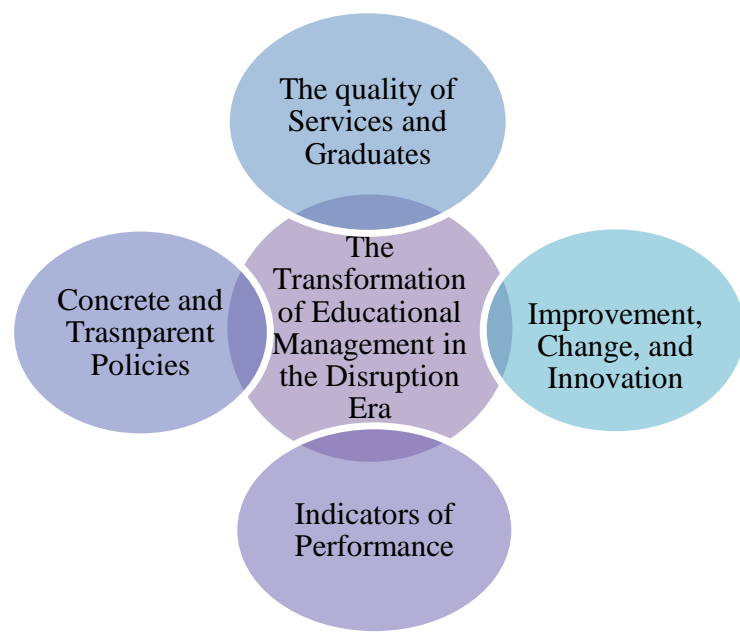

Image: The Design of the Transformation of Educational Management in the Disruption Era

These four variables are the basic principles of transforming educational management and they influence each other in operating educational management in the disruption era.

\section{The Transformation of Educational Management in the Disruption Era}

The transformation of educational management in the disruption era is a demand of times in facing global life of industrial revolution 4.0. It continues to encourage educational institution and stakeholders to transform educational management that is centered on the achievement of service quality and students, leadership who has vision and mission that create concrete and transparent 
policies, to organize human resources who are able to make improvements, changes and innovations, as well as to build a culture that creates the indicators of performance.

\section{Concentration of the Achievement of Service and Graduate Quality}

The success of implementing educational programs is not based on the quantity of output but it is based on the achievement of service and graduate quality (Prasetyo \& Sutopo, 2018). The indicator of a nation's success is not determined by abundant natural resources but it is largely determined by the quality of human resources (Zulela, 2020).

The quality of academic services and graduates in educational institution is through three important pillars namely literacy, competence, and character (Zulela, 2020). Through these three pillars, it will create the creative and innovative human resources. Creative and innovative using in this context means having human resources who are able to compete and have skills in their everyday life.

The realization of these three pillars could be transformed through the disruption of the traditional education system to a digitalization system for online activities. The online system could be in the form of innovative MOOC (Massive Open Online Course) and AI (Artificial Intelligence) application. MOOC is an online learning innovation designed to be open, able to share, and to connect or network with each other. Meanwhile, AI is an artificial intelligence machine that is designed to help and make it easier to do specific and individual jobs in searching and presenting information in a fast, accurate and interactive way (Zulela, 2020).

\section{Vision and Mission that Give Concrete and Transparent Policies}

The vision and mission of an educational institution must be able to produce concrete and transparent policies. It could be realized through the programs, activities and budget provided. All of this must be done transparently to generate internal and external trust in realizing the vision and mission of an educational institution (Hayat: 2014).

The vision and mission that is transformed by means of disruption could produce concrete policies that are contained in the programs and activities to be carried out by the members of the education institution and also give concrete 
policies as a form of innovation and the responsibility of the leadership to develop the educational institution towards a better direction and keep moving forward.

The disruption of transparency must be used as the main asset in educational leadership. It could build trust in all forms of policy, formulation, implementation, finance, monitoring, and evaluation (Hayat: 2014). It is as a medium for social information on the educational institution environment, grows trust, kinship, and a sense of belonging to the educational institution.

\section{Organizing Human Resources to Make Improvements, Changes, and Innovations}

Human resources have a very strategic position in an organization, so it is very important to organize the human resources (Mongilong, et.al., 2018: 4). Organizing human resources is not only limited to division of tasks and delegation of authority but it is very crucial to foster, train, and provide opportunities for the staff to make improvements, changes and innovations.

Qualified educational stakeholders are those who have positive competitiveness in their work (Herman, 2020). Competitive stakeholders could produce works or products that could satisfy customers or users. The higher the quality of work or product, the higher the competitiveness of the individual in administering educational programs (Zulela, 2020).

The organization of human resources must be transformed, so the staff could have the ability to make improvements, changes, and innovations in the management of educational institution (Hayat: 2014). Improvements and changes that arise from the staff is because they have the courage to innovate their work. The higher the ability of the staff to innovate, the more opportunities are opened for the governor to make improvements and changes at any time and in stages to show progress and real results in the short term (quick win) (Mongilong, et.al., 2018).

\section{Work Culture that Generates the Indicators of Performance}

Organizational culture is as the norms and habits accepted by everyone in certain organization (Astutik, 2017). It is used as a common guide of communication in an educational organization. A good work culture could be realized by giving praise to employees who work well and reprimand employees who violate the rules that have been set together (Gani, 2019). If a group of 
people joins an organization, it certainly brings the values and beliefs that have been taught or become habits in an organization.

A good work culture could be built through the mastery of soft skills. Soft skills could influence the behavior and they would care about the quality and create programs and activities quickly, precisely and efficiently and they also respect time and reputation (Djohonegoro, 1998). The formation of soft skills is carried out from an early age through a process of work habituation that is developed and aligned with work needs and the progress of times in the disruption era (Hamidah \& Palupi, 2012).

A good and strong work culture will produce clear and measurable indicators of performance (Septadi \& Zunaidah, 2014). Work culture must be transformed to produce the indicators of performance by mobilizing elements of management in an integrated way. It is impossible for the indicators of performance to grow and develop well if they are not supported by an adequate budget. An adequate budget is also not sufficient if it is not supported by qualified human resources. Then funds and human resources also mean nothing if there are no programs and activities to be carried out.

\section{CONCLUSION}

The management of educational units in the disruption era can encourage the leaders and educational stakeholders to transform the management in an integrated and comprehensive manner to achieve the quality of academic services and graduates. Educational leadership has a vision to create concrete policies in implementing educational programs. Organizing human resources can create strong, courageous, and committed members of the education unit to make improvements and changes as well as to continuously make innovations towards the progress of the education unit. Building a culture of work is connected to the performance indicators, and improve the quality of educational unit management. 


\section{REFERENCES}

Abdul Rouf, Transformasi, dan Inovasi Manajemen Pendidikan Islam, Manageria Manajemen Pendidikan Islam, Volume 1, Nomor 2, November 2016

Abidin, N., Sandy, G. A., \& Hasan, H. (2020). Analisis Kualitas Layanan Pendidikan Terhadap Tingkat Kepuasan Mahasiswa Pada Perguruan Tinggi Swasta Di Kabupaten Manokwari Papua Barat Tahun 2019. Pedagogik: Jurnal Pendidikan, 15(1), 27-39.

Ali, N. M., Jangga, R., Ismail, M., Kamal, S. N. I. M., \& Ali, M. N. (2015). Influence of leadership styles in creating quality work culture. Procedia Economics and Finance, 31, 161-169.

Arifin Mongilong, Frans Singkoh, dan Josef Kairupasi, Pengembangan Kapasitas Aparatur Sipil Negara Dalam Meningkatkan Prosionalisme Kerja Di Badan Pengelola Keuangan dan Aset Daerah Kabupaten Bolaang Mongondow, Eksekutif Jurnal Jurusan Ilmu Pemerintahan, Fakultas Ilmu Sosial dan Politik Universitas Sam Ratulangi, Volume 2, No. 2 Tahun 2018

Bohemia, E., Rieple, A., Liedtka, J., \& Cooper, R. (2014). Proceedings of the 19th DMI: Academic Design Management Conference: Design Management in an Era of Disruption.

Djohonegoro, Wardiman, Pengembangan Sumber Daya Manusia Melalui SMK, Jakarta: Jayakarta Agung Offset, 1998

Fitri, A. Z. (2020). HASIL PEER REVIEW" The New Paradigm of Prophetic Education in the Disruption Era of Industrial Revolution 4.0". European Union Digital Library, 1(1), 36-44.I

Farid Abdullah, Fenomena Digital Era Revolusi Industri 4.0, Jurnal Dimensi DKV Seni Rupa dan Desain, Volume 4, Nomor 1, April 2019

Gani, H. (2019). Upaya Meningkatkan Budaya Kerja Tenaga Pendidikan Dan Tenaga Pendidikan Melalui Penerapan Reward And Punishment Di SMP Negeri 8 Gorontalo. Ideas: Jurnal Pendidikan, Sosial dan Budaya, 5(2), 221-236.

H. Prasetyo \& W. Sutopo, Industri 4.0: Telaah Klasifikasi Aspek dan Arah Perkembangan Riset, Jurnal Teknik Industri, (13/1), 2018

Hairiyah, Konsep Manajemen Mutu Terpadu Dalam Pendidikan, Literasi, Volume VI, No. 1, Juni 2015 
Hayat, Konsep Kepemimpinan Dalam Reformasi Birokrasi: Aktualisasi Pemimpin Dalam Pelayanan Publik Menuju Good Governance, Jurnal Borneo Administrator, UIN Malang, Volume 10, No. 1, Tahun 2014

Herman, Perilaku Komunikasi Kepala Sekolah Dalam Peningkatan Kinerja Guru, Idarah Jurnal Pendidikan dan Kependidikan, IAIN Lhok Seumawe, Vol. 4, No. 1, januari -Juni 2020

Jamaluddin, J., Salam, R., Yunus, H., \& Akib, H. (2017). Pengaruh budaya organisasi terhadap kinerja pegawai pada dinas pendidikan provinsi sulawesi selatan. Jurnal Ad'ministrare, 4(1), 25-34.

Kartini Kartono, Pengantar Metodelogi Risetv Sosial, Bandung: Mandar Maju, 1996

Khoiri, M. (2020). Visionary Leadership on Transforming Organizational Change in the Era of Disruption. International Journal of Multicultural and Multireligious Understanding, 7(10), 490-495.

Kurbani, A. (2019). Pengaruh Kualitas Layanan Akademik Dan Fasilitas Pendidikan Terhadap Kepuasan Mahasiswa Kuliah pada Universitas PGRI Palembang. Jurnal Media Wahana Ekonomika, 13(4).

Kusjono, G., \& Sudjiani, E. (2019). Pengaruh Kualitas Layanan Pendidikan Terhadap Kepuasan Peserta Didik Di Sma Islam Cikal Harapan Bumi Serpong Damai. Jurnal Ilmiah Feasible (Jif), 1(1), 83-94.

M. Anton Septadi, dan Zunaidah, Pengaruh Budaya kerja Terhadap Produktivitas Kerja Karyawan Bagian Pelayanan PDAM Tirta Musi Palembang Unit Rambutan, Jembatan-Jurnal Ilmiah Manajemen Bisnis dan Terapan, Tahun XI, Nomor 2, Oktober 2014

Mahmud, Manajemen Pendidikan Tinggi Berbasis Nilai-Nilai Spiritulitas, Bandung, PT Remaja Rosdakarya, 2019

Maisah, Transformasi Pendidikan Perempuan Dari Tradisional Ke Moderen di Seberang Kota Jambi, Junal Kafa’ah, 9 (1), 2019, ISSN 2356-0630, 2019

Mardi Astutik, Pengaruh Disiplin Kerja, dan Budaya Organisasi Terhadap kinerja Pegawai Sekretariat Dewan Perwakilan Rakyat Daerah Kabupaten Jombang, Jurnal Bisnis, Manajemen \& Perbankan, Vol. 2, Nomor 2, 2016

Mayling Oey Gardiner, dkk, Era Disrupsi Peluang, dan Tantangan Pendidikan Tinggi Indonesia, Jakarta Pusat, Akademi Ilmu Pengetahuan Indonesia, Cet. II, 2017

Nazir Mohammad, Metode Penelitian, Jakarta: Chalia Indonesia, 1988 
122 | TAZKIR: Jurnal Penelitian Ilmu-ilmu Sosial dan Keislaman

Vol. 07 No. 1 Juni 2021

Siti Hamidah dan Sri Palupi, Peningkatan soft skills Tanggung Jawab dan Disiplin Terintegrasi Melalui Pembelajaran Praktek Patiseri, Jurnal Pendidikan Karakter,Tahun II, Nomor 2, Juni 2012

Sudjiani, E., Subarto, S., \& Kusjono, G. (2019). Pengaruh Citra dan Kualitas Layanan Pendidikan terhadap Kepuasan Peserta Didik di Sekolah Cikal Harapan. Jurnal Ilmiah Feasible (JIF), 1(2), 123-137

Zulela MS, M.Pd, Dr, Prof "Transformasi Pendidikan Dasar di Era Disrupsi dalam Pengembangan Karakter”, Prosiding Seminar Nasional 2020, Program Studi PGSD STKIP PGRI Bandar Lampung, 6 Maret 2020 